\title{
Acquisition of Wh-questions in English by Persian Monolinguals and Iranian Arab Bilinguals
}

\author{
Marzieh Galbat \\ Islamic Azad University, South Tehran Branch, Tehran, Iran \\ Roohollah Maleki \\ Shahid Sattari University of Aeronautical Technology \& Science, Tehran, Iran
}

\begin{abstract}
This study intended to incorporate some insights to the newly-explored field of third language acquisition. To this end, it investigated the acquisition of wh-questions movements in English by 2nd and 3rd language learners within Universal Grammar (UG) structure. After taking the Nelson Proficiency Test, 102 Persian mono-lingual and Arabic-Persian bilingual learners of English were assigned to two proficiency groups. A Grammaticality Judgment Test (GJT) was administered to measure the subjects' performance on English difference types of wh-questions. In spite of the fact that the structure of wh-questions was similar in Arabic and English, but different in Persian, the results showed no significant difference between the performance of monolinguals and bilinguals, but significant differences were found between the elementary and intermediate learners on various types of wh-questions in English. That is to say, the findings of the study regarding language transfer in 3rd language acquisition lead to the conclusion that the source of crosslinguistic effect in 3rd language acquisition is probably more of the learners' 2nd language than their 1st language.
\end{abstract}

Index Terms —wh-question movement, monolinguals, bilinguals, UG, GJT, elementary, intermediate

\section{INTRODUCTION}

While there is an abundance of research on second language acquisition (L2A) and the effects of the first language on the acquisition of the second, little is known about third language acquisition (L3A) and the effects of the two already known languages on the acquisition of the third. The research on the acquisition of a language other than the mother tongue is so dominated by L2A that whenever the issue of foreign language teaching and learning is discussed, especially in educational institutes; one does not assume any role to the first local languages known by people in multilingual communities. In such institutes, the national standard language is assumed as the first language for the whole population without any noticeable attention to knowledge of languages other than the national language carried by the students. While many such do not yet know the national language up to the age of schooling, their mother tongue is their sole linguistic tool in exploring the world and communicating with others in their beginning years of life. In curriculum preparation, similarly, what seems important in second or foreign language teaching and learning is the contrast between the national language and the target language. Since a noticeable number of people in the world are bilinguals, the issue of third language acquisition, in fact, is one of the basic issues in foreign language research. In such particular settings like Iran, in which bilingualism for students at schools and universities is taken for granted, it seems appropriate to study the effects of the first language (mother tongue) and the second language (Persian) on the acquisition of the third language (English as a foreign language).

This research is to continue this research tradition by adding to the issue of the nature and the extent of transfer of the first languages into the syntax of adult learners of 2nd language generally and especially 3rd language. This research is limited to the questions of transfer within the syntactic domains in general to achieve this goal. Generative 2nd language acquisition research is in no way restricted to the debate of transfer, because transfer alone cannot prepare an absolute clarification for the improvement paths taken by non-native language students. It is essential of generative 2nd language learning research to focus on the influence of UG in 2nd language learning. Generative 2nd language investigators always link transfer to extent to which UG restrains 2nd language acquisitions. So this research embarks the claim whether English L3 learners' discrete language background makes them expand inter-language patterns which are dissimilar or alike to those of mono-lingual English learners. That is, the main question formulated in this study is the influence of the beforehand learned languages on the 3rd inter-language patterns and the amount to which the L3 learners' production in view of the syntactic features engaged in the formation of English questions would be the same or different from that of L2 learners. In this scope, the impact of the language background acquired by Arabic-Persian bilingual learners of English will be explored through comparatively considering the most current syntactically- based generative models of L2 acquisition, i.e. Full Access/Full Transfer (FAFT) and the Failed Functional Feature 
Hypothesis (FFFH). The performance of the Arabic-Persian bilinguals on the English questions which entail the syntactic aspects of head and Wh-movement will be contrasted with that of Persian mono-lingual learners within this framework. This comparative study may help to demonstrate whether L3 acquisition is different from L2 acquisition or it is merely another case of L2 acquisition.

\section{REVIEW OF THE RELATED LiTERATURE}

\section{A. Theoretical Framework}

Different theories of second language acquisition make different predictions with respect to both the role of transfer and the ultimate attainment (that is, whether or not the acquisition of the L2 syntactic properties, i.e., wh-movement, is possible for L2 learners). The transfer, is concerned with the question of to what extent the properties of the L1 grammar influence L2 acquisition (White, 2003). Two theories which posit L1 transfer are Full Transfer/Full Access theory (FT/FA) (Schwartz \& Sprouse, 1996) and the Representational Deficit Hypothesis (RDH), formally known as the Failed Functional Feature Hypothesis (FFFH) (Hawkins \& Chan, 1997). Both theories consider the L1 grammar to be the starting point for the acquisition of L2. On the other hand, Direct Access theory (Epstein, Flynn, \& Martohardjono, 1996) considers the Universal Grammar (UG) to be the starting point for the acquisition of L2.

\section{B. Wh-movement Parameters}

UG is "the system of principles, conditions and rules that are elements or properties of all human languages" (Chomsky, 1976, p. 29). Then, Chomsky (1981) differentiates these universals as composing of principles and parameters. Radford (1997) believes the language faculty is composed of a group of 'principles of universal grammar (UG)'. On the other hand, grammatical learning is not going to engage in learning those features of grammar which are established by universal grammatical principles and operations. However, grammatical learning will be constrained to those parameters of grammar which are subject to language special variation. To say that in another way, grammatical learning will be restricted to parameterized features of grammar. The understandable way to distinguish just what aspects of the grammar of their first language children have to learn is to scrutinize the set of parametric variation appeared in the grammars of different natural languages.

The Wh-Parameter is one parameter of variation among languages- a parameter which specifies whether whexpressions are fronted or not. Considerably, this parameter again seems to be one which is binary in nature since it allows for just two probabilities. Movement is an important point in Wh-questions. Movement is a process in generative grammar and a syntactic process by which elements move and leave behind silent trace copies. Movement was structured from the early 1970s move[s] as few constituents as probable the shortest distance probable (Radford et al., 2009). Movements are either A-movements or A-bar movements. In cases where an expression, such as an NP, is moved to a location that can only be filled by argument expressions, like the case of passivization, A-movement happens, while in items where an expression, for instance a Wh-phrase, is moved to a position that can be filled by both arguments and adjuncts, A-bar movement happens (Radford, 2004). Head-movement is another kind of syntactic movement, like the cases where a V moves to I (Hawkins, 2001).

Wh-movement is acceptable and it is compulsory for all wh-expressions in English. As an illustration, in the interrogative structures below the wh-expressions are time and again moved to the front of the structures:

(3a) She visited her friend.

$$
\text { Who }
$$

(3b) She visited who?

(3c) Who did she visit

(4a) She went to the park.

$$
\text { Where }
$$

(4b) She went where?

(4c) Where did she go t?

$$
\text { 个 }
$$

As you see, the wh-expressions - who and where - which used instead of the verb complements of visited and went in the interim structures of (3b) and (4b) correspondingly, have moved to the front of the parallel structures in (3c) and (4c). As a consequence, all wh-expressions in English interrogative structures must systematically be fronted Radford (1997).

Nonetheless, it appears that this claim again does not confirm to be correct concerning Farsi in interrogative structures. Farsi grammar lets for both possibilities for some wh-expressions. They can both stay in situations and move to the front of the general structure or happens immediately after or before the subject in some items. For example:

(5a) /hamid beh ketabkhaneh raft/.

Hamid to ketabkhaneh went

(5b) /hamid kojaa raft/? (Where did Hamid go?)

Hamid where went?

(6a) /reza beelate bimaari beh doctor raft/. 
Reza because of sickness beh doctor raft

(6b) /reza chera beh doctor raft /? (Why did Reza went to the doctor?)

Reza why beh doctor raft?

At the first look one may mistakenly conclude that Farsi constantly does not let the wh-expressions (i.e., /cheraa/, /kojaa/, /barayecheh/, /kii/, and so forth.) to move and they systematically remain in situations. Still, this is not the case with the use of (/cheraa/) in certain interrogative structures; for instance:

(7a) /Amir be park naraft chon hava barani bood/.

Amir to park did not go because it was rainy.

(Amir did not go to park because it was rainy)

*(7b) /Amir be park naraft cheraa/?

Amir to park did not go why

(Why did not Amir go to park ?)

(7c) /cheraa amir be park naraft/?

Why Amir to park did not go

(7d) /amir cheraa be park naraft/?

Amir why to park did not go

If we remove the clause (/chon hava barani bood /) and replace it with the parallel wh-expression (/cheraa/), subsequent the no-wh-movement rule which was pointed to earlier, the ill-formed structure (7b) results. In this certain case, the wh-expression (/cheraa/) is not allowed to stay in situation by Farsi grammar and has to move either to the front or to immediately after the subject. Consequently, the position of the wh-expression in the interim structure, i.e. after the related elments are erased and replaced with the proper wh-expression-is grammatically acceptable, the whexpression will remain in situation; if not, it has to move. As a result, in Farsi, for most of the wh-expressions in interrogative structures, it seems that there is no wh-movement, or, if there exists any, it is very restricted. However, in case of the wh-expression (/cheraa/), we saw that its movement to front of the structure or immediately after the subject was compulsory in particular structures.

The formation of wh-questions in Arabic resembles English since in both languages the syntactic movement of whphrase to (Spec-CP) is recognized. In Arabic C bears $\mathrm{Q}$ and [wh]. The strong [wh] in $\mathrm{C}$ triggers the wh-phrase to move to Spec-Cp (Benmamoun, 2000).

(10) /yaqru Ahmed alqasedata/.

Read pres Ahmed the poem.

Ahmed reads the poem.

(11) [cp Matha, [IP yaqru Ahmed ti] ?

What read pres Ahmed

What does Ahmed read?

The above account of Question formation in English, Persian and Arabic highlights reveals parametric difference and similarities among the three languages regarding the formation of interrogative structures. As to English and Persian, the latter is a wh-in-situ language but English entails the syntactic wh-movement to Spec-CP and head movement from I to C. Conversely, Arabic appeared to resemble English because the formation of wh-questions in Arabic entails the movement of wh-phrase to Spec-CP, but C stays empty.

\section{The Role of the L1 and Universal Grammar in Second Language Acquisition}

UG-based L2 research has focused on the L2 initial state since the mid-1990s. One of the major questions is whether L2 learners employ all or parts of the $1^{\text {st }}$ language grammar as their initial theory of the target language. Five partly overlapping positions on the L2 initial state vary from each other regarding the influence they assign to L1 transfer and UG. Each of these positions will be reviewed here.

\section{Full Transfer/Full Access}

According to this hypothesis, the L1 and L2 acquisition differ at their initial state but seem to be quite comparable with reference to the access of UG. In this theory the starting point is different because L1 learners do not know anything about another language by birth and can hardly even communicate. By comparison, L2 learners have a different point of origin and all categories are transferred, considered to be significant and the $U$ G is completely accessible to the learner. Furthermore, the learner is not supposed "to be stuck with L1 parameter setting; instead, parameter resetting to the $\mathrm{L} 2$ value is possible, on the basis of input from the L2 interacting with a still active UG". In this approach, the role of the first language is as important as the role of the Universal Grammar. Finally, the learner stage of acquisition seems to come close to a native-like proficiency, with the help of UG.

According to White (1988), both L1 learners and L2 learners have direct access to UG. During SLA, L2 learners start out with parameters set to their L1 values. This entails that full transfer takes place from the L1 to the L2. However, these transferred L1 parameter values merely constitute the initial state of SLA, and are by no means the sum of the aspects of UG to which the L2 learners have access. On White's view, L2 learners have full access to UG.

Where parameter values of the L1 and the L2 differs, parameter resetting needs to take place during SLA. This resetting will take place if the input to which the L2 learner is exposed contains the relevant positive evidence, i.e. evidence that the target L2 instantiates a parameter value that differs from the value instantiated in the learner's L1. 
Where positive evidence is not sufficient to bring about the desired change from the L1 parameter value to the correct L2 parameter value, this change has to be brought about through exposure to negative evidence, exposure to direct evidence in the form of corrective feedback or explicit instruction (ibid.).

\section{Full Transfer/No Access}

In full transfer/no access model, the L1 last state is the preliminary state of L2 acquisition. Access to Universal Grammar is by the use of the L1, therefore if the Universal Grammar rule is not accessible in the L1, it is not accessible in second language acqusition. Bley-Vroman (1990) claims that UG itself is not available during SLA, but that a surrogate UG is accessible through the L2 learner's knowledge of his/her L1. The L2 learner constructs this surrogate UG from his/her L1 knowledge (Bley-Vroman, 1989). This indirect knowledge is accidental and incomplete (ibid.) and serves as the explanation for the variable success that adult L2 learners exhibit in SLA.

According to Bley-Vroman (1996, p. 718), Fundamental Difference Hypothesis "permits UG-like effects via the L1". In other words, the L2 learner does not have access to UG, but observes aspects of UG instantiated in his/her L1 (aspects such as structure dependency). The L2 learner expects certain things from the L2 because of his/her L1 knowledge; these expected things include a syntax, a lexicon, a phonological system with syllables, feet and phonological phrases, as well as the potential for an infinite number of sentences to be generated in the L2 (BleyVroman, 1989). The L2 learner makes use of these "expectations", as well as various general cognitive mechanisms (not specifically linguistic, according to Bley-Vroman (1996, p. 718) in the construction of the L2.

\section{Partial Transfer/Full Access}

In order to this concept, Universal Grammar is fully accessible while only definite parts of L1 are transferred. Following this approach, L2 learners start to acquire in a similar way as L1 learners. The difference is that they already know another language before starting to learn a second one. Second language learners continuously design functional categories in response to the L2 input. L1 learners usually act in the same way. They combine parts of L1 with a complete UG to learn their target language. To sum up, it seems as if the learner could reach a complete achievement.

The partial transfer/full access model was originally proposed by Vainikka and Young-Scholten (1996). In this model, it is claimed that only lexical categories are found in the initial L2 grammar. Functional categories are not transferred from L1 to L2 so that the initial state of L2 learners' grammar consists of the projections of NP and VP (with L1 headedness). DP, TP and CP will emerge at a later stage with interaction of the L2, in principle, L2 learners should converge on the L2 grammar. In this respect, the L2 learner's initial state is just like the initial state proposed by Radford (1990) for children acquiring their L1. Moreover, According to Vainikka and Young-Scholten's (1994), pp. 267-268) Minimal Trees Hypothesis, L2 learners have direct, but initially limited, access to UG in SLA. What is meant by "initially limited access" is that L2 learners start out with only lexical projections (hence "Minimal Trees"), transferred from the L1, and then acquire functional projections gradually on the basis of the L2 input and with the aid of UG. Like White, Vainikka and Young-Scholten (ibid.) claim that L2 learners start out with the L1 parameter values and then reset the parameters during SLA where necessary.

\section{Partial Transfer/Partial Access}

This approach could be explained as a combination of the essential factors of the role of UG, L1 and other acquisition faculties mentioned before. The role of UG is acknowledged to be very important in L1 and L2 acquisition. In SLA it is likely to have a partial transfer of L1 features and access of fundamental parts of UG. Moreover, this concept postulates that L2 learners use general learning strategies as well. White (1998) holds the view that Universal Grammar is only one component in the theory of language acquisition and interacts with a variety of others. Unsuccessful acquisition is attributed to other areas and not implicitly to non-operation of UG. In addition, Ellis terms this argument "dual access" and explains that adult L2 learners can only reach the ultimate attainment if they rely on UG. Since Universal Grammar is only partially accessible for L2 learners, it seems like they will not be able to achieve a native-like competence. Only parts of the L1 grammar are available. Ultimate attainment of an L2 is not possible. Fig. 2 illustrates this.

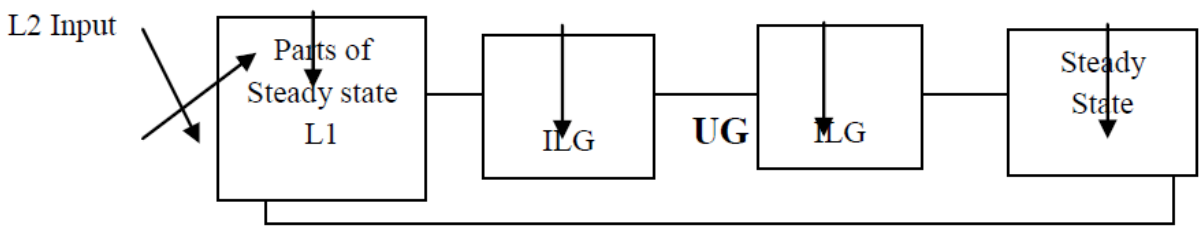

Figure 2. Partial transfer/partial accesses

\section{No Transfer/Full Access}

This is the only concept where the transfer from L1 to L2 is totally refused. Contrastively, there is a full access to the UG. It is believed that the L2 grammar is learned on account of UG rules and strictures, which interrelate straightforwardly with the L2 input. The L2 initial state does not contain the L1 final state or any developmental phase. UG is assumed to constitute the initial state for L2 acquisition. All properties of UG are available for L2 acquisition, including new parameter setting, functional categories and feature values. Thus, L2 acquisition proceeds just like L1 acquisition [11]. We can predict that the present L2 learners will show no clear L1-influenced stage, they will never produce a "John what ate?" structure. 


\section{METHODOLOGY}

\section{A. Research Questions and Hypotheses}

This study intends to answer the following questions:

1. Is there any statistically significant difference between Iranian mono-lingual learners (L1 Persian) and PersianArab bilingual learners (L1 Arabic, L2 Persian) in their acquisition of formation of simple wh-questions in English?

2. Is there any statistically significant difference between elementary and intermediate learners in the acquisition of wh-question movements in English?

Based on the above research questions, the following two null hypotheses were formulated:

1. There is no difference between Persian-Arab bilingual learners (L1 Arabic, L2 Persian) and Persian mono-lingual learners (L1 Persian) in the acquisition of wh-question movements in English.

2. There is no significant difference between elementary and intermediate learners in the acquisition of wh-question movements in English.

\section{B. Participants}

Overall, 102 participants took part in the study. There were 48 Arabic-Persian bilinguals (L1 Arabic, L2 Persian) and 54 Persian mono-lingual (See Table 1. for details).

TABLE1.

OVERVIEW OF THE PARTICIPANTS

\begin{tabular}{|l|l|l|l|l|}
\hline & Mono-lingual & Mono-lingual & bilinguals & bilinguals \\
\hline Proficiency level & elementary & intermediate & elementary & intermediate \\
\hline Number of participants & 30 & 24 & 26 & 22 \\
\hline Age range & $16-18($ mean=17) & $16-21($ mean=18/5) & $16-18($ mean=17) & $16-21(\mathrm{mean}=18 / 5)$ \\
\hline
\end{tabular}

This study was undertaken among second and third language learners and instructors of English in Bandar-e-Lengeh. It was essential to target a primary population from which the participants in this study were selected. This primary population was required to include bilingual and mono-lingual English learners. The bilingual learners were in a linguistic community where both parents were Arabs and they use the Arabic dialect of Bandar-e-Lengeh as their native language. Moreover, their first and most dominant language is Arabic. They use it at home and in most informal situations outside the school with their friends. The Iranian Arab group started their official learning of Persian when they entered school at the age of 6. From then on they studied almost all their academic subjects in Persian. They use Persian extensively in their everyday life as they have to use Persian as an official language for communication outside Arab linguistic community and they have been exposed to it in classroom situations, on TV and radio programs. So, they were near native speakers of Persian as well.

The Persian mono-lingual group had very little knowledge of Arabic as they live in a neighboring region to Bandar Lengeh, which is inhabited by Persian monolingual speakers.

Bilingual and mono-lingual learners were at two levels of proficiency, namely, elementary and intermediate. The elementary learners were third year of high school students in Bandar Lengeh. They all had studied English as a foreign language for 5 to 6 years. Their age ranged from 16 to 18 years. In order to maintain the same level of English language proficiency for all the participants, a homogenous test had administered to the participants. The intermediate learners were selected among institution in Bandar-e-Lengeh. Their age ranged from 16 to 21 years.

\section{Instruments}

The following instrumentations were utilized in this study: A standard general English proficiency test, Nelson Test was used to determine the participant's level of proficiency in English and ensuring their homogeneity. This test comprised 50 multiple-choice of vocabulary, grammar, and reading comprehension items. Its reliability was estimated in a pilot study by 35 students who had the same characteristics to the main participants of this study. Its reliability reached 0.91 through Cronbach's Alpha Formula. And its content validity also was confirmed by four knowledgeable EFL instructors.

In addition, a background questionnaire was used to elicit some personal information about participants' background. Furthermore a GJT (see the APPENDIX) along with a correction task was utilized to examine the participants' syntactic knowledge. This test was devised to see how the participants perform on the formation of English simple wh-questions. The participants were asked to judge whether a given sentence was grammatical or ungrammatical in English. The correction task required subjects to correct those sentences which were judged to be ungrammatical in English. The purpose of the correction task was to ensure that subjects were rejecting sentences for the right reasons. The GJT had around 40 sentences to be judged. Sixty of these 40 ones were ungrammatical, and 16 sentences were grammatical. There were 8 fillers among 40 items. Among the ungrammatical ones, 5 of them were fillers. Therefore, there were 32 test items. There were eight types of wh-questions (how, where, when, who, what, whose, which, and why) among these 32 test items. Also, there were 4 items for each type of wh-question (e.g. there were 4 items of how, 4 items of what, and etc.). Before administering The GJT, it was piloted 35 students who had the same features to the main 
participants of this study, and its reliability was estimated 0.78 through Cronbach's Alpha method. Also its content validity also was verified by four experienced and knowledgeable EFL teachers.

\section{Procedure}

Data was collected in four 2-hour sessions and the learners were wanted to perform on the prouction test. For the purpose of data collection, two types of tests were prepared to measure the L2 \& L3 learners' ability in formation, judgment and interpretation of English questions. The tests administered in two different places. The tests for bilinguals and mono-linguals at elementary level administered in public high school and for L2 and L3 learners at intermediate level administered in an institute in Bandar-e-Lengeh. During first session, the participants were asked to complete a background questionnaire which was used to elicit some personal information about participants' backgrounds. After of doing sampling procedure and choosing subjects randomly, 148 students were initially asked to the participate in the study. Then, the Nelson Test was administered. In this stage participants received some instructions to respond to 50 items in the test. The Nelson Placement Test was administered to 148 participants. Those students whose proficiency score were one standard deviation, 9.21 below and above the mean of 27.85 were selected as homogeneous participants for this study. Therefore 102 students whose score were between 18 and 37 were chosen.

Having carried out the first test, the participants took the other test, that is, a grammaticality judgment test. The test was intended to analyze the participants' performance on English simple wh-questions and see how well the participants perform on different types of wh-questions.

This test comprised 40 two-choice items on the basis of wh-movements. Sixty out of 40 items were grammaticality and the other 16 items were in ungrammaticality. There were 8 fillers items among 40 items. Therefore, there were 32 test items. Then, the participants were asked read the wh-question sentences and to judge whether given the whquestions sentences such as examples 1 and 2 were acceptable in English or not, p.

1. *Does Ali where live? good bad

2. Who is the author of that book? $\operatorname{good} \quad \operatorname{bad}$

However, the participants were asked to circle "good" if they thought those were possible sentences in English, otherwise to circle "bad". The participants were wanted to correct them in the given spaces for the randomly were selected sentences if you thought they are "bad". Also, the participants were told to observe the time limit and they were not allowed to go back to any previous test items. They were asked not to correct or erase what they supply as their first response. In all sessions, care was taken to observe similar testing environments. The test instructions were given in Persian. The test sentences were presented on a sheet of paper, and subjects answered them on the same paper. There were different versions of the test with the test sentences in random order to control for ordering effects. Before commencing the tasks, the participants were told that they could ask questions if they had any difficulty in understanding the items.

As to format, the test was prepared in the form of a checkbook to let the participants focus on one item at a time. This test was also presented in the form of a checkbook including eight types of different wh-words (which, what, how, who, whose, why, where, and when). Of course, the selected items were scrambled randomly in the final version to guarantee that the participants would not be able to guess the possible similarity between the items concerning the grammatical functions of wh-words. Using this format helped the test taker to control the allotted time (one minutes for responding to each item) and see that the participants are doing one test item at a time.

\section{E. Data Analysis}

The results of the main test items in each test were measured in the following way. With respect to the grammaticality judgment task each chosen grammatical wh-question sentence was given a score of one and each wrong response was given zero.

The performance of the two groups of participants and the two levels were compared on wh-questions movements using quantitative, descriptive and inferential statistics. The degree of the similarity or dissimilarity of the means of the two groups of participants will be shown in graphs. In order to determine the similarity or difference between the performances of the both mono-lingual and bilingual groups and two elementary and intermediate levels, parametric Independent Samples Test was applied. And the nonparametric Mann-Whitney U Test was run to compare the judgment scores for mono-lingual learners and bilinguals at elementary and intermediate on each wh-question movement per se.

\section{F. Design}

Descriptive research is planned to illustrate a situation as it naturally occurs. It may be employed to judge and to develop theories. A descriptive study is one in which information is collected without changing the environment (i.e., nothing is manipulated). For the purpose of this study, descriptive studies are usually the best methods for collecting information that will demonstrate relationships and describe the bilinguals and monolinguals in learning wh-questions as it exists. This research design leads to explain and quantify an incident. The data collected are from quantitative kinds to describe and quantify. 
The purpose of study was to investigate differences and similarities between the bilingual and mono-lingual learners in acquisition of wh-questions. However, the wh-questions were dependent variable and the bilingual and mono-lingual learners were independent variable. Also, the participants of study selected randomly. The quantitative data based on precise measurements using structured and validated data-collection instruments. The data displays comparisons means and statistical significance of findings.

\section{RESULTS}

\section{A. Homogeneity Process}

To ensure the homogeneity of the participants, the Nelson Placement Test was administered to 148 participants. Those students whose proficiency score were one standard deviation, 9.21 below and above the mean of 27.85 were selected as homogeneous participants for this study. Therefore 102 students whose score were between 18 and 37 were chosen. The descriptive statistics of the participants' scores on this test are set forth in Table 2.

This Table shows the descriptive analysis of research such as range, minimum score, maximum score, mean, median, mode, standard deviation and variance.

TABLE 2.

DESCRIPTIVE STATISTICS OF NELSON PLACEMENT TEST

\begin{tabular}{|l|l|l|l|l|l|l|l|l|}
\hline $\mathrm{N}$ & Range & Min. & Max. & Mean & Median & Mode & SD & Variance \\
\hline 148 & 42 & 6 & 48 & 27.85 & 28.00 & 26 & 9.215 & 84.917 \\
\hline
\end{tabular}

In order to Figure out whether the data is normally distributed, we used Kolmlgrov-Smirnoff Non-parametric test.

This normality test showed the Sig. of .96 , which is more than .05 , based on the data which we may consider that the scores are normally distributed $(p=.96, p>\alpha)$.

Then those students whose proficiency score were one standard deviation below the mean (scores from 18 to $28, n=$ 56 students) were considered as elementary participants, and those students whose proficiency score were one standard deviation above the mean (scores from 29 to 37, $n=46$ students) were assigned into intermediate group.

The descriptive statistics of the participants' scores at Elementary and Intermediate Levels on this test are represented in Table 3.

TABLE 3.

DESCRIPTIVE STATISTICS OF PARTICIPANTS' SCORES AT ELEMENTARY AND INTERMEDIATE LEVELS

\begin{tabular}{|l|l|l|l|l|l|l|l|l|l|}
\hline Parameter & $\mathrm{N}$ & Range & Min. & Max. & Mean & Median & Mode & SD & Variance \\
\hline Elementary & 56 & 10 & 18 & 28 & 23.62 & 24.00 & 26 & 3.096 & 9.584 \\
\hline Intermediate & 46 & 8 & 29 & 37 & 32.54 & 32.00 & 29 & 2.622 \\
\hline
\end{tabular}

\section{B. Testing the First Null Hypothesis}

In order to see whether mono-lingual and bilingual participants' scores were normally distributed, KolmogorovSmirnov Normality Test was applied. The results showed that two groups' scores are normally distributed because Sig. for mono-lingual and bilingual participants' scores were not significant and they were 0.28 and 0.10 respectively $(p>$.05). Therefore, Independent Samples Test which is Parametric was used to compare the mean score of two groups to see whether the first null- hypothesis of this research should be rejected or not.

The mono-lingual and bilingual participants' performances on Grammaticality Judgment Test (GJT) were assessed, and Table 4. represents the related results. As clarified in the table, there were 54 mono-lingual learners with a mean score of 28.63 and standard deviation of 2.36, and 48 bilinguals with a mean score of 29.15 and standard deviation of 2.39. In fact, the mean score and standard deviation of the two groups are not far from each other denoting that the participants in the two groups have close knowledge of the formation of simple wh-questions in English.

TABLE 4.

DESCRIPTIVE STATISTICS OF BILINGUALS AND MONO-LINGUALS' WH-QUESTION MOVEMENT SCORES

\begin{tabular}{|l|l|l|l|l|l|l|l|l|}
\hline Group & $\mathrm{N}$ & Range & Min. & Max. & Mean & Median & Mode & SD \\
\hline Mono-lingual & 54 & 9 & 23 & 32 & 28.63 & 28.50 & 27 & 2.36 \\
\hline Bilingual & 48 & 8 & 24 & 32 & 29.15 & 30.00 & 31 & 2.39 \\
\hline
\end{tabular}

In order to compare the Wh-question movement mean scores of participants in both mono-lingual and bilingual groups, first the Levene's Test was used to determine the equality of variances and to show that the data are homogeneous. Then an Independent Samples Test was applied to determine the equality of means.

Levene's Test in Table 5 shows that the hypothesis of equal of variances was supported because Sig. for equality of variance, .65, was greater than .05; Moreover, T-test results in the table indicates that there was not a significant difference between the wh-question movement mean scores of mono-lingual and bilingual participants $(t=-1.09, p$ $=.27, p>.05)$ in which the $t$-observed, 1.09 was lower than the $t$-critical, 1.98 , with 100 degrees of freedom, and $p$ 
value, .27 was greater than the .05 level of significance. Accordingly, the first null hypothesis of this study was retained, and it can be claimed that there is not any statistically significant difference between Persian-Arab bilinguals (L1 Arabic, L2 Persian) and Persian mono-lingual learners (L1 Persian) in the acquisition of wh-question movements in English.

TABLE 5.

INDEPENDENT SAMPLES TEST FOR COMPARISON MONO-LINGUAL AND BILINGUAL PARTICIPANTS' TOTAL JUDGMENT SCORES

\begin{tabular}{|l|l|l|l|l|l|l|}
\hline Levene's Test for Variances & \multicolumn{3}{|c|}{ T-test for Means } & Mean Diff. \\
\hline & F & Sig. & t & df & Sig. (2-tailed) & -.516 \\
\hline
\end{tabular}

Fig. 3 provides us with a graphical representation of the results. The figure displlays the difference between monolingual and bilingual participants' wh-question movement mean scores is small. Thus, the bilinguals got a slightly higher mean score than the mono-lingual learners but it indicated that there weren't significant difference across the groups on wh-questions in grammaticality judgment task.

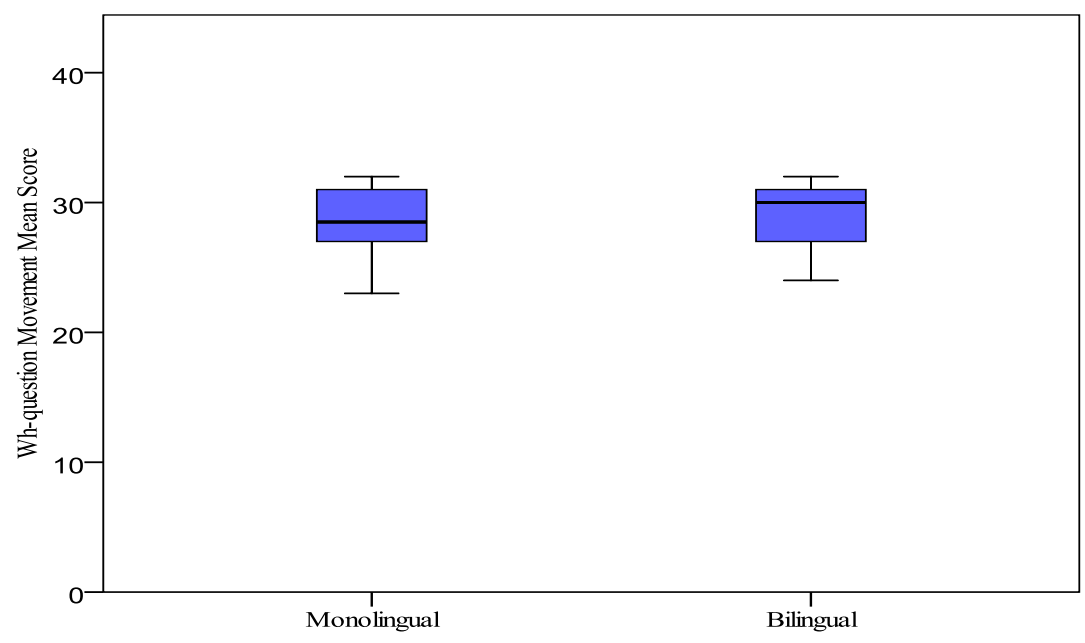

Figure 3. Mono-lingual and bilingual participants' wh-question movement means scores

We saw that the performance of the Arab bilingual group, although a little bit higher, did not differ significantly from the performance of the Persian mono-lingual group. What can we say about this? Don't our bilinguals transfer parameters from Arabic into English as it is assumed by Failed Functional Features Hypothesis and Full Transfer/Full Access Model?

This similarity in the performance of our two groups could be the influence of the second language (i.e. Persian) on the learning of English as a third language. In addition, the influence of the first language of bilinguals seems to be less than the influence of the second language in third language acquisition. It is likely that third language learners transfer more settings from their second language in the inter-language of the third language.

\section{Testing the Second Null Hypothesis}

The second null hypothesis of this study proposed, "There is no significant difference between elementary and intermediate learners in the acquisition of wh-question movements in English". In order to check this null hypothesis, Independent Samples Test was used.

Before conducting the t-test, the descriptive statistics of grammaticality judgment scores in the two groups were calculated (See Table 6). It shows that the intermediate group $(n=56)$ with mean score of 30.24 and standard deviation of 1.66 xceeded the elementary group $(n=46)$ with the mean score of 27.75 and standard deviation of 2.30.

TABLE 6.

DESCRIPTIVE STATISTICS OF ELEMENTARY AND INTERMEDIATE PARTICIPANTS' WH-QUESTION MOVEMENT SCORES

\begin{tabular}{|l|l|l|l|l|}
\hline Level of Proficiency & $\mathrm{N}$ & Mean & Std. Deviation & Std. Error Mean \\
\hline Elementary & 56 & 27.75 & 2.306 & .308 \\
\hline Intermediate & 46 & 30.24 & 1.662 & .245 \\
\hline
\end{tabular}

Fig. 4 below displays the results graphically. As clear in the Fig. 4, significant differences were found between performances of the elementary L2 \& L3 learners and the performance of the intermediate mono-lingual learners and 
bilinguals. However, the intermediate L2 \& L3 learners obtained higher mean scores than the elementary bilinguals and mono-lingual learners in production of wh-questions movements.

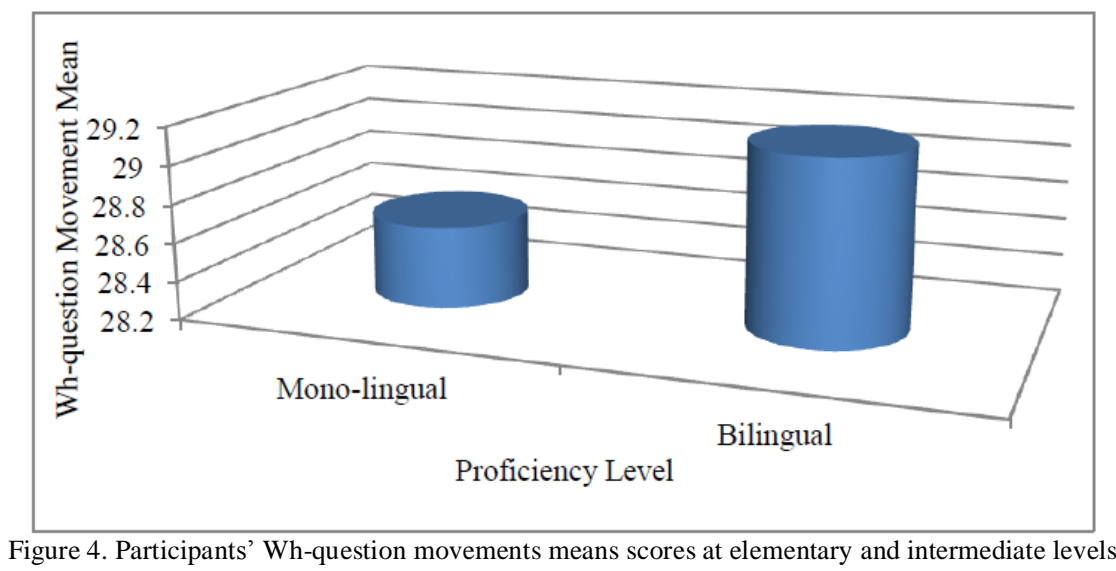

In order to see whether elementary and intermediate participants' Wh-question movement mean scores were normally distributed, Kolmogorov-Smirnov Normality Test was applied. The results of this analysis indicated that two groups' scores were normally distributed since Sig. for elementary and intermediate participants' scores were .12 and .07 respectively which are both more than .05 . Therefore, the parametric Independent Samples Test was utilized to compare the mean score of two levels to see whether the second null- hypothesis of this research should be rejected or not.

In order to compare the wh-question movement mean scores of the participants at elementary and intermediate levels, first the Levene's test was used to determine the equality of variances. Then the $t$-test was applied out to determine the equality of means.

Levene's Test in Table 7 reveals that the hypothesis of equal of variances was proved since Sig. of .08 was higher than .05 . The table provides us with enough criteria for the rejection of the second null hypothesis of this study that reads "There is no significant difference between elementary and intermediate participants' scores in the acquisition of wh-question movements in English" $(t=-6.12, p=.000, p<.05)$ in which the $t$-observed, 1.09 was less than the $t$ critical, 1.98, with 100 degrees of freedom, and $p$ value, .000 was less than the .05 level of significance. As a result, with high degree of confidence, it can be claimed that there is a significant difference between elementary and intermediate participants' scores in the acquisition of wh-question movements in English.

TABLE 7.

INDEPENDENT SAMPLES TEST OF COMPARISON BETWEEN PARTICIPANTS’ WH-QUESTION MOVEMENT MEAN SCORES AT ELEMENTARY AND INTERMEDIATE LEVELS

\begin{tabular}{|l|l|l|l|l|l|l|}
\hline \multicolumn{2}{|l|}{ Levene's Test for Variances } & \multicolumn{4}{l|}{ T-test for Means } \\
\hline & F & Sig. & t & df & Sig. (2-tailed) & Mean Diff. \\
\hline Equal variance assumed & 3.161 & .082 & -6.12 & 100 & .000 & -2.489 \\
\hline
\end{tabular}

In order to more details of the second null hypothesis of the research, we compared the judgment scores on eight types of wh-questions movements at elementary and intermediate levels.

One-Sample Kolmogorov-Smirnov Test results revealed that the scores obtained on all eight wh-question movements were not normally distributed since Sig. for all of them was less than $.05(p<.05)$; thus, the nonparametric MannWhitney U Test was run to compare the judgment scores at elementary and intermediate on each wh-question movement per se. Mann-Whitney U Test (see Table 8) detected statistically significant differences in five wh-question movements, i.e. How $(p=.000, p<.05)$, where $(p=.000, p<.05)$, Who $(p=.002, p<.05)$, When $(p=.005, p<.05)$, and What $(p=.042, p<.05)$ question movements across the levels since the $p$ values for these five wh-question movements in Mann-Whitney Test were less than .05; however, Mann-Whitney U Test results revealed that there were not significant differences in the three of them, i.e. Whose $(p=.104, p>.05)$, Which $(p=.157, p>.05)$, and Why $(p=.269$, $p>.05$ ) between the two levels of language proficiency because the $p$ values for these three wh-question movements were greater than .05 . 
TABLE 8.

MANN-WHITNEY U TEST TO COMPARE THE MOVEMENT MEAN SCORES OF EACH WH-QUESTION AT TWO LEVELS

\begin{tabular}{|l|l|l|l|l|}
\hline Wh-question Type & Mann-Whitney U & Wilcoxon W & Z & Sig. (2-tailed) \\
\hline How & 744 & 2340 & -3.888 & .000 \\
\hline Where & 814 & 2410 & -3.6 & .000 \\
\hline Who & 899.5 & 2495.5 & -3.118 & .002 \\
\hline When & 946 & 2542 & -2.806 & .005 \\
\hline What & 1055 & 2651 & -2.036 & .042 \\
\hline Whose & 1128 & 2724 & -1.624 & .104 \\
\hline Which & 1152.0 & 2748 & -1.417 & .157 \\
\hline Why & 1193 & 2789 & -1.106 & .269 \\
\hline
\end{tabular}

\section{DISCUSSION}

Independent Samples Test results for testing the second null hypothesis of the current study as there is not any statistically significant difference between Persian-Arab bilinguals (L1 Arabic, L2 Persian) and Persian mono-lingual learners (L1 Persian) in the acquisition of wh-question movements in English indicated that this null hypothesis was not rejected $(t=-1.09, p=.27, p>.05)$.

Also, T-Test detected a significant difference between elementary and intermediate participants' scores in the acquisition of wh-question movements in English, and therefore the second null hypothesis was rejected $(t=-6.12, p$ $=.000, p<.05)$.

Besides, for deeper investigation, Mann-Whitney $U$ Test found statistically significant differences in five whquestion movements, i.e. How, where, Who, When and what $(p<.05)$ question movements between the levels. But, it failed to find any significant difference in the three of them, i.e. Whose, Which and Why between the two levels of language proficiency $(p>.05)$.

Persian mono-lingual learners of L2 English were available at different levels of proficiency. But this was not the case with Arabic-Persian learners of L3 English. Due to their relatively small population and several other reasons, it was difficult to find a reasonable number of Arabic-Persian learners of L3 English at higher proficiency levels. In other words, selecting a sample of advanced L3 learners turned to be difficult because of the certain qualities such a group should possess.

The findings of this study coincide with Schwartz and Sprouse's (1996) opinion that acquiring will fail where L1 and L2 parameter contexts diverge, i.e. parameter resetting in the L2 is not possible after the critical period for instantiation of these parametric values has made to function. As a result, the inter-language (IL) syntactic representations in postchildhood $2^{\text {nd }}$ language acquisition would be different from the target grammar not considering evident native-like presentation.

Our study also lends support to Li's (1998) research that found that UG is accessible to adult L2 learners when they reach a high proficiency level in the target language. She claims that the native-like performance of the US group is featured to a high language proficiency that helps learners fully access UG and is not attributed to the age of the learners.

Moreover, the results of this study are in line with Sikogukira's (1993) findings about French- English cognates. The results of his study showed that the level of proficiency is a very important factor influencing the performance of the learners and the transfer in the language acquisition.

\section{CONCLUSION}

Considering to the impact of language background in L3 acquisition, the findings of the current study resulted in the conclusion that bilingualism makes no significant advantage in 3rd language acquisition. Of course, in some cases the bilingual learners performed better than the mono-lingual ones but not considerably. This seems that the bilingual learners may not take full advantage of their discrete language background as their performance was not more important than that of the mono-lingual learners. That is to say, Arab-Persian bilinguals could also benefit from the accessibility of the [+wh] aspect in their 1ast language to develop their L3 inter-language grammar considering the formation of English simple wh-questions. Nonetheless, the results of this research elucidated that the L3 and L2 learners' presentation were constant and the L3 learners did not act drastically higher than the mono-lingual learners even though their first language, Arabic, shared [+wh] with English.

The finding of the study showed that there was a significant difference between elementary and intermediate participants' performance in the acquisition of wh-question movements in English.

The intermediate L2 \& L3 learners performed better than the elementary L2 \& L3 learners on wh-questions acquisition. Also, the overall results of the study showed that that all eight wh-question movements are not significantly different for mono-lingual and bilingual learners but there were many different between at two levels of proficiency. Moreover, it showed that How, Where, Who, When, and What-question movements were dramatically different at two levels but Whose, Which, and Why were not significantly different at two levels of proficiency. Finally, it can be claimed that there is no significant difference between Persian-Arab bilinguals (L1 Arabic, L2 Persian) and Persian monolinguals (L1 Persian) in the acquisition of wh-question movements in English. But significant differences were 
found between performances of the elementary L2 \& L3 learners and the performance of the intermediate mono-lingual and bilingual learners.

\section{IMPLICATION}

The findings of the study tend to contribute to the theoretical and practical advancement of L2A and L3A. As to theoretical contribution, the findings can benefit multi-lingualism and in particular, the L3A. In terms of cross-linguistic influence, it was shown that more of L2 was reflected in L3 inter-language grammar than their L1 as the finding of the study made it clear that the L3 and L2 learners' performance on English interrogative constructions were consistent. In other words, the L3 learners did not act considerably better than the mono-lingual learners even though their 1st language Arabic contributes to [+wh] with English. This insight seems to support the Full Transfer part of the FTFA hypothesis and to be in accord with the claim of "the last language effect" according to which the most recently acquired language is more available for transfer (Hammarberg, 2001). Accordingly, it can be claimed that L3A is different from L2A.

Third language learners constitute a big number of adult language learners around the world. The findings of this study showed that the theories of second language acquisition cannot be applied to these learners. Furthermore, the L2A theories have to be reformulated in light of the findings of L3A studies. If more attention is paid to the study of third language acquisition, it would illuminate not only L2A, but also L1A. Consequently, language acquisition researchers cannot generalize L2A theories into third language acquisition. Rather, they should pay special attention to L3A, L4A, etc, which are not unusual instances in today's world.

The present study also provided empirical data which indirectly helped the development of inter-language theory; the pieces of evidence supplied in different phases of the study contributed to the confirmation and disconfirmation of predictions of the most recently generative models of L2A and their extension of L3A. Moreover, it provided insights into the effect of language learners variable- in terms of impact of language background- on the process of L2A/L3A in that the bilingual learners are not advantaged over mono-lingual learners.

Third language learners come to the task of the acquisition of L3 with bigger reservoirs of knowledge compared to second language learners. They know one more language. The task of the L3 teacher becomes more complicated as one more, big factor is added to the process of language acquisition. If this teacher can find the similarities and differences of the third language with the previously learned languages, he/she can make the process of L3A faster and smoother for the learners. As the findings of this study suggest, when L2 and L3 are different in an aspect, the second language is more influential in L3A even if the L1 and L3 are similar in that aspect. The knowledgeable teacher can bring the similarities of L1 and L3 into the consciousness of his/her students. By doing so, he/she can accelerate the process of L3A, which is already a little bit faster than L2A, as we saw in the results of this study.

Finally, this study appears to contribute to bilingualism research. That is to say it provides some insights into the influence of bilingualism on multi-lingual acquisition. The empirical data reported in this study implied no beneficial effects of bilingualism on third language acquisition as it was revealed that the Arab-Persian bilinguals did not outperform their mono-lingual counterparts. This implication is compatible with the results of some studies on bilingualism which focused on the specific areas of language proficiency and found no significant difference between the bilingual and mono-lingual learners' learning English as a foreign language (Jaspaert \& Lemmens, 1990; Zobl, 1993).

\section{APPENDiX. GRAmMATICALITy JudGMENT TeST (GJT)}

Please read the wh-question sentences and circle "Good" if you think these are possible sentences in English, otherwise circle "Bad". Please provide corrections in the given spaces for the randomly selected sentences if you think they are "bad".

\begin{tabular}{|c|c|c|}
\hline $\begin{array}{l}\text { 1. Does Ali where live? } \\
\ldots \ldots \ldots \ldots \ldots \ldots \ldots \ldots \ldots\end{array}$ & Good & $\mathrm{Bad}$ \\
\hline 2. Did you go to the bank this morning? & Good & $\mathrm{Bad}$ \\
\hline 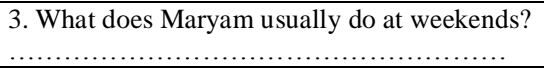 & Good & $\mathrm{Bad}$ \\
\hline $\begin{array}{l}\text { 4. Why did Mohsen get up early? } \\
\ldots \ldots \ldots \ldots \ldots \ldots \ldots \ldots \ldots \ldots \ldots \ldots \ldots \ldots \ldots \ldots \ldots \ldots\end{array}$ & Good & Bad \\
\hline $\begin{array}{l}5 . \text { Will the new machine how work? } \\
\ldots \ldots \ldots \ldots \ldots \ldots \ldots \ldots \ldots \ldots \ldots \ldots \ldots \ldots \ldots \ldots\end{array}$ & Good & $\mathrm{Bad}$ \\
\hline $\begin{array}{l}\text { 6. Do you know where he is? } \\
\ldots \ldots \ldots \ldots \ldots \ldots \ldots \ldots \ldots \ldots \ldots \ldots \ldots \ldots \ldots\end{array}$ & Good & $\mathrm{Bad}$ \\
\hline $\begin{array}{l}\text { 7. Will Maryam choose which dress? } \\
\ldots \ldots \ldots \ldots \ldots \ldots \ldots\end{array}$ & Good & $\mathrm{Bad}$ \\
\hline $\begin{array}{l}8 . \text { Where is your mother? } \\
\ldots \ldots \ldots \ldots \ldots \ldots \ldots \ldots \ldots\end{array}$ & Good & $\mathrm{Bad}$ \\
\hline $\begin{array}{l}\text { 9. Whose glasses were you wearing? } \\
\ldots \ldots \ldots \ldots \ldots \ldots \ldots \ldots \ldots \ldots \ldots \ldots \ldots \ldots \ldots \ldots \ldots \ldots\end{array}$ & Good & $\mathrm{Bad}$ \\
\hline
\end{tabular}




\begin{tabular}{|c|c|c|}
\hline $\begin{array}{l}\text { 10. Are you waiting for who? } \\
\ldots \ldots \ldots \ldots \ldots \ldots \ldots \ldots \ldots \ldots\end{array}$ & Good & Bad \\
\hline $\begin{array}{l}11 . \text { Did he ask many questions? } \\
\ldots \ldots \ldots \ldots \ldots \ldots \ldots \ldots \ldots \ldots \ldots \ldots \ldots \ldots \ldots \ldots \ldots \ldots \ldots \ldots\end{array}$ & Good & $\mathrm{Bad}$ \\
\hline $\begin{array}{l}12 . \text { When was the telephone invented? } \\
\ldots \ldots \ldots \ldots \ldots \ldots \ldots \ldots \ldots \ldots \ldots \ldots \ldots\end{array}$ & Good & $\mathrm{Bad}$ \\
\hline 13. Did you have for lunch what? & Good & Bad \\
\hline 14. Who is the author of that book? & Good & $\mathrm{Bad}$ \\
\hline $\begin{array}{l}\text { 15. Does Mohammad usually study when? } \\
\ldots \ldots \ldots \ldots \ldots \ldots \ldots \ldots \ldots \ldots \ldots \ldots \ldots \ldots \ldots\end{array}$ & Good & $\mathrm{Bad}$ \\
\hline $\begin{array}{l}\text { 16. What are they listening to? } \\
\ldots \ldots \ldots \ldots \ldots \ldots \ldots \ldots \ldots \ldots \ldots\end{array}$ & Good & $\mathrm{Bad}$ \\
\hline $\begin{array}{l}17 . \text { Making she is eggs for breakfast today? } \\
\ldots \ldots \ldots \ldots \ldots \ldots \ldots \ldots \ldots \ldots \ldots \ldots \ldots \ldots \ldots \ldots\end{array}$ & Good & $\mathrm{Bad}$ \\
\hline $\begin{array}{l}\text { 18. Are you why angry with me? } \\
\ldots \ldots \ldots \ldots \ldots \ldots \ldots \ldots \ldots \ldots\end{array}$ & Good & Bad \\
\hline 19. Did they build how that bridge? & Good & $\mathrm{Bad}$ \\
\hline $\begin{array}{l}\text { 20. Jack whose car did borrow? } \\
\ldots \ldots \ldots \ldots \ldots \ldots \ldots \ldots \ldots \ldots \ldots\end{array}$ & Good & $\mathrm{Bad}$ \\
\hline 21. Are your parents going for their holiday where? & Good & $\mathrm{Bad}$ \\
\hline $\begin{array}{l}22 . \text { Why did Sarah stay at home? } \\
\ldots \ldots \ldots \ldots \ldots \ldots \ldots \ldots \ldots \ldots\end{array}$ & Good & Bad \\
\hline 23. Why do you know the cat is sleeping outside? & Good & $\mathrm{Bad}$ \\
\hline $\begin{array}{l}24 . \text { How is he doing to travel to Tabriz? } \\
\ldots \ldots \ldots \ldots \ldots \ldots \ldots \ldots \ldots \ldots \ldots \ldots \ldots \ldots \ldots\end{array}$ & Good & $\mathrm{Bad}$ \\
\hline $\begin{array}{l}25 . \text { Was the doctor talking to who? } \\
\ldots \ldots \ldots \ldots \ldots \ldots \ldots \ldots \ldots \ldots \ldots \ldots\end{array}$ & Good & $\mathrm{Bad}$ \\
\hline $\begin{array}{l}\text { 26. Will Hamid do his homework when? } \\
\ldots \ldots \ldots \ldots \ldots \ldots \ldots \ldots \ldots \ldots \ldots \ldots \ldots \ldots \ldots \ldots \ldots \ldots \ldots \ldots \ldots \\
\end{array}$ & Good & $\mathrm{Bad}$ \\
\hline $\begin{array}{l}\text { 27. Which clothe does he like? } \\
\ldots \ldots \ldots \ldots \ldots \ldots \ldots \ldots \ldots \ldots\end{array}$ & Good & $\mathrm{Bad}$ \\
\hline $\begin{array}{l}\text { 28. Came Helen did to the party? } \\
\ldots \ldots \ldots \ldots \ldots \ldots \ldots \ldots \ldots \ldots \ldots \ldots\end{array}$ & Good & $\mathrm{Bad}$ \\
\hline $\begin{array}{l}\text { 29. Whose shoes are these? } \\
\ldots \ldots \ldots \ldots \ldots \ldots \ldots \ldots \ldots\end{array}$ & Good & $\mathrm{Bad}$ \\
\hline $\begin{array}{l}\text { 30. When will they be here? } \\
\ldots \ldots \ldots \ldots \ldots \ldots \ldots \ldots \ldots\end{array}$ & Good & $\mathrm{Bad}$ \\
\hline $\begin{array}{l}\text { 31. Who did Ali hit? } \\
\text {................. }\end{array}$ & Good & $\mathrm{Bad}$ \\
\hline $\begin{array}{l}\text { 32. Did Akbar show what to his grandmother? } \\
\ldots \ldots \ldots \ldots \ldots \ldots \ldots \ldots \ldots \ldots \ldots \ldots \ldots \ldots \ldots \ldots\end{array}$ & Good & $\mathrm{Bad}$ \\
\hline $\begin{array}{l}\text { 33. Does Mr. Mohseni teach how English? } \\
\ldots \ldots \ldots \ldots \ldots \ldots \ldots \ldots \ldots \ldots \ldots \ldots \ldots \ldots \ldots\end{array}$ & Good & $\mathrm{Bad}$ \\
\hline $\begin{array}{l}\text { 34. Are your friends staying at hotel? } \\
\ldots \ldots \ldots \ldots \ldots \ldots \ldots \ldots \ldots \ldots \ldots \ldots \ldots\end{array}$ & Good & $\mathrm{Bad}$ \\
\hline $\begin{array}{l}35 . \text { Shall we go which way? } \\
\ldots \ldots \ldots \ldots \ldots \ldots \ldots \ldots \ldots \ldots\end{array}$ & Good & $\mathrm{Bad}$ \\
\hline $\begin{array}{l}\text { 36. Where has Amir forgotten his keys? } \\
\ldots \ldots \ldots \ldots \ldots \ldots \ldots \ldots \ldots \ldots \ldots \ldots \ldots\end{array}$ & Good & $\mathrm{Bad}$ \\
\hline $\begin{array}{l}37 . \text { Didn't he accept why the account? } \\
\ldots \ldots \ldots \ldots \ldots \ldots \ldots \ldots \ldots \ldots \ldots \ldots \ldots \ldots\end{array}$ & Good & $\mathrm{Bad}$ \\
\hline $\begin{array}{l}38 . \text { Why do you know she went home? } \\
\ldots \ldots \ldots \ldots \ldots \ldots \ldots \ldots \ldots \ldots \ldots \ldots \ldots\end{array}$ & Good & $\mathrm{Bad}$ \\
\hline $\begin{array}{l}\text { 39. Is grammar book on the table whose? } \\
\ldots \ldots \ldots \ldots \ldots \ldots \ldots \ldots \ldots \ldots \ldots \ldots \ldots \ldots \ldots \ldots \ldots \ldots \ldots \ldots \ldots \\
\end{array}$ & Good & $\mathrm{Bad}$ \\
\hline $\begin{array}{l}\text { 40. Which doctor did you see? } \\
\ldots \ldots \ldots \ldots \ldots \ldots \ldots \ldots \ldots \ldots\end{array}$ & Good & $\mathrm{Bad}$ \\
\hline
\end{tabular}

\section{REFERENCES}

[1] Benmamoun, E. (2000). The Feature Structure of Functional Categories. New York: Oxford University Press.

[2] Bley-Vroman, R. (1989). What is the logical problem of foreign language learning? In S.M. Gass and J. Schachter (eds.) Linguistic perspectives on second language acquisition. Cambridge, New York and Melbourne: Cambridge University Press. pp. 41-68.

[3] Bley-Vroman, R. (1990). The logical problem of foreign language learning. Linguistic Analysis 20, pp. 3-49.

[4] Bley-Vroman, R. (1996). What we have to explain in foreign language learning. Behavioral and Brain Sciences 19 , p. 718.

[5] Chomsky, N. (1976). Conditions on rules of grammar. Linguistic Analysis 2, pp. 303-351. 
[6] Chomsky, N. (1981). Lectures on government and binding. Dordrecht: Foris.

[7] Epstein, S., Flynn, S. and Martohardjono, G. (1996). Second language acquisition: theoretical and experimental issues in contemporary research. Brain and Behavioral Sciences 19, pp. 677-714.

[8] Hammarberg, B. (2001). "Roles of L1 and L2 in L3 Production and Acquisition". In: Cenoz, J., Hufeisen, B. \& Jessner, U. (eds.) Cross-linguistic Influence in Third Language Acquisition. Clevedon: Multilingual Matters, pp. 21-41.

[9] Hawkins, R. (2001). The theoretical significance of Universal Grammar in second language acquisition. Second Language Research 17, pp. 345-367.

[10] Hawkins, R. \& Chan, Y. (1997). The partial availability of Universal Grammar in second language acquisition: the 'failed functional feature hypothesis'. Second Language Research 13, 187-226.

[11] Jaspaert, K. \& Lemmens, G. (1990) Linguistic evaluation of Dutch as a third language, in: M. BYRAM\&, J. LEMAN (Eds) Bicultural and Trilingual Education (Clevedon), pp. 30-57.

[12] Radford, A. (1997). Syntactic theory and the structure of English: a minimalist approach. Cambridge: Cambridge University Press.

[13] Radford, A. (2004). Minimalist syntax: Explaining the structure of English. Cambridge: Cambridge University Press.

[14] Radford, A., Atkinson, M., Britain, D., Clahsen, H., \& Spencer, A. (2009). Linguistics: An introduction (2nd Ed.). Cambridge: Cambridge University Press.

[15] Schwartz, B. D. \& Sprouse, R. A. (1996). "L2 cognitive states and the Full Transfer/Full Access model." Second Language Research, Vol.12, No. 1, pp. 40-72.

[16] Vainnika, A. and Young-Scholten, M. (1994). Direct access to X'-theory: Evidence from Korean and Turkish adults learning German. In T. Hoekstra and B. Schwartz (eds.) Language acquisition studies in generative grammar. Amsterdam and Philadelphia: John Benjamins, pp. 265-316.

[17] Vainikka, A. and Young-Scholten, M. (1996). Partial transfer, not partial access. Behavioral and Brain Sciences, 19, pp. 744-5.

[18] White, L. (1988). Island effects in second language acquisition. In S. Flynn and W. O’Neil (Eds.), Linguistic theory in second language acquisition. Dordrecht, Boston and London: Kluwer Academic Publishers, pp. 144-172.

[19] White, L. (2003). Second Language Acquisition and Universal Grammar. Cambridge: Cambridge University Press.

[20] Zobl, H. (1993). Prior linguistic knowledge and the conservation of the learning procedure: Grammaticality judgments of unilingual and multilingual Learners. In S. M. Gass \& L. Selinker (eds.), Language Transfer in Language Learning, 176196.Amsterdam: John Benjamins.

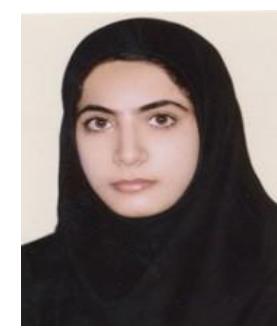

Marzieh Galbat was born in Bandar-lengeh, Iran in 1983. He has an MA in TEOFL from Islamic Azad University, South Tehran Branch. She teaches English at some High schools and English language Institutes in Bandar-lengeh, Iran.

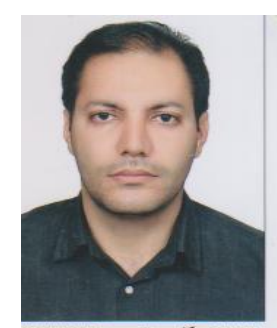

Roohollah Maleki was born in Nahavand, Iran in 1980. He holds MA in TEOFL from Islamic Azad University, South Tehran Branch. He teaches in the English Center at Shahid Sattari University of aerotical Technology and Science, Tehran, Iran. His research interests are second and third language acquisition, contrastive analysis, discourse analysis, testing and material development. He has published several articles in language learning acquisitions e.g. "Attribution for Failure of English Majors Students vs. their Instructors" published by International Journal of Language Learning and Applied Linguistics World in April 2014. 